\title{
Mingle Model for Teaching English Speaking Skill for College Students
}

\author{
Darmayenti $^{* 1}$ \\ Faculty of Adab and Humanities, State Institute for Islamic Studies Imam Bonjol Padang,West Sumatera \\ ${ }^{I}$ E-mail: darmayentid@yahoo.com
}

Nofel Nofiadri

Faculty of Adab and Humanities, State Institute for Islamic Studies Imam Bonjol Padang, West Sumatera

E-mailnofelnofiadri@yahoo.com

DOI: http://dx.doi.org/10.15548/it.v22i1.115

\begin{abstract}
This paper is a report of a research and development project conducted in a speaking skill for the firstyear students of State Institute for Islamic Studies Imam Bonjol Padang, academic year 2012/2013. Mingle as a technique in teaching speaking proposed by Pollard and Hess in 1997 was developed into a new model. Using ADDIE model as proposed by Dick and Carey in 1996, we collected the intended data through observation, questionnaire, and test. The result of the research showed that the implementation of model gave a significant difference in term of the students-learning outcome between the students who are taught through Mingle model and by traditional one or without Mingle model. The development of Mingle model included preparation, warming up, set the rule, act Mingle model, presentation, review and discussion. It is concluded that Mingle model is more effective to improve students on all components of speaking skill. Therefore, it is recommended that this model can be implemented at IAIN Imam Bonjol Padang.
\end{abstract}

Keywords: Mingle model, speaking skill, college students

\section{INTRODUCTION}

English is one of compulsory subjects which should be taken by the students at the first and the second semesters at State Institute for Islamic Studies (IAIN) Imam Bonjol Padang. The main objective of the instruction is to provide students with good performance of English so that they are able to participate in various academic activities. Officially, the objective of teaching English is to develop student's English language skills in listening, speaking, reading and writing. Therefore, to enable the students to communicate both spoken and written in English fluently, they should acquire all four important language skills and other language components such as grammar, vocabulary, pronunciation, etc. It is also expected that by acquiring those skills and components, the students can express their ideas and thoughts as well as perform communication well. It implies that teaching process should be shifted from talking about language to doing something with language.

However, based on the preliminary observation and interviews, many students still got problem in speaking. Nofiadri (2010) found that the average students had difficulty to say something in English because they had some problems which do not support them to speak correctly. The first reason is that they are lack of vocabulary. Students will be restricted to express their ideas and then they will use code mixing. Secondly, students cannot speak fluently because the students do translation in the time they produce English. So, the effect is that they take time to speak and their language adopts Bahasa Indonesia grammar-bahasa Indonesia sounded. Thirdly, they have problem on grammar. It sometimes makes them afraid to speak. For example, they construct a complex sentence in Bahasa Indonesia to tell the idea and feeling, but they do not know how to manage complex sentence in English. So then, they will try to avoid the idea to speak. In other case, the students also have low comprehension about what lecturers say that will be shown by the students' responses. In addition to this weakness, they prefer to keep silent instead of saying something in English in the classroom. They worry about making mistakes, fearful of criticism or losing face or simply shy of attention their speech 
attracts. Sometimes they complain that they cannot think of anything to say. They seem to have no motivation to express themselves beyond the feeling of guilty that they should speak, while other speaks very little or not at all. Since they have no motivation, lack of support and peer pressure so, in teaching speaking skills in the L2 classroom, it is not enough merely to provide with opportunities to speak in English.

One way to develop students' competency in speaking English well is through repairing teaching process gradually. English teaching focusing on speaking should be more emphasized on individual attention in order to gain teaching purpose. Teaching process should be handled warmly, joyfully, unthreatened, and challenging. Therefore, lecturers should be able to create meaningful atmosphere, joyfully, creative, dynamic and dialogic of education (Law No 20/2003; Law No $14 / 2005$ and law No 37 / 2009). In order to improve students' skill on speaking individually well, it is important to develop a new relevant model on students' need and characteristics.

One of the models which can be developed on speaking class is Mingle. Mingle which is proposed firstly by Pollard and Hess (1997) can be modified into a new model for teaching speaking skill. Formerly, it is an activity or technique in which the students stand up and circulate with one another, and talk to people especially at a social event and various topics (talking cocktail party style) (Pollard and Hess, 1997:29). The unique one of a Mingle activity is that the students stand up and circulate simultaneously, in pairs or small groups, and switch from one classmate to another while speaking, listening, and taking notes. Face-to-face interaction with at least a few other students is the principal goal. It comes as a set of 20 cards and each card has a unique question designed specifically for the group. Mingle activity is started by asking different student with the same question and different responses learn through talk, activities are conducted by moving and walking, use card as a media, use peer and small group of students, base students centered, and lecturer is part of students, and fun. Mingle activities include class questionnaires, matching activities (finding partner), group dictations, and role-plays. The activity does serve an important purpose. It gets students talking and forming sentences. It is repetitive and helps them recognize patterns.
Mingle has two steps, act mingle and do presentation. On the activity of Mingle, the students do the following activities; (1) The students are shared the card, (2) The students read the information in the card, (3) The students do the conversation through moving and walking down, and (4) lecturer controls and facilitates the students. On the presentation, the students do the following activities; (1) the students present the result of Mingle, (2) lecturer gives reward to the winner. The result of previous test was shown the students got difficulties to start to speak. In practice, it should be developed into some steps which can be used easily by the students in doing speaking.

Based on the background information of teaching speaking at Institute for Islamic Studies, this research aimed at developing Mingle as a new model to be used to teach speaking skill. The previous research found that students' speaking skill in Elementary and Junior Hugh School can be improved by using Mingle (Darmayenti, 2003; 2011). However, the teacher should explain the rule and the materials first to help the students to start to speak. Mingle was modified for the students who use English as a foreign language at Islamic Studies (IAIN) Imam Bonjol Padang. In addition, this research was conducted to find out the effect of Mingle model toward students' skill on speaking. Mingle is designed to be a communicative model in teaching speaking skill in order to explore students' speaking skills.

\section{METHOD}

A research and development type was used to develop Mingle model for teaching speaking skill at English class at Institute for Islamic Studies Institute Padang. Research and development as the findings of research can be used to design new product (Borg and Gall (2003:569). ADDIE model which proposed by Dick and Carey (1996) was adopted to develop the Mingle model. ADDIE model reflects a systematic approach to develop teaching process.

There were five ways to be conducted namely, Analysis, Design, Development, Implementation, and Evaluation. ADDIE model reflects a systematic approach to develop teaching process. The five steps were conducted as follows. First, analysis or preliminary study of the problem. There were some activities had been done namely analyze students' need on speaking skill, analyze 
material, and teaching process. On teaching process, the activity was focused on preparation, teaching process- technique or method is used. Second, designing outline of model. In designing the teaching model, the activity should be started by doing need assessment. Therefore, there were some criteria should be analyzed. Model should (1) be oriented on students; (2) be based competence and style of learning, (3) be based on system approach, (4) be empirically tested. The model was designed will guidance for teachers or lecturers in planning the teaching process in the classroom, includes preparation, media, evaluation, and way to gain the aim of teaching. Third, developing of model.. Developing of this model was started by implementation the old Mingle technique. After doing teaching speaking through the old mingle, it could be concluded that the old Mingle should be modified into the appropriate one since that the students were difficulties to start to speak in English. The modification of this model was written on the lesson plan. Developing of Mingle model follows should have (1) syntax is the activity sequence or phases, (2) social system is the role of teacher or lecturer and students and types of rule are used, (3) principle reaction is the way of teacher to response students' comment (4) supporter system, namely condition needed by model, and (5) impact of instructional impact, namely result to reach by teacher and students after following study (Joyce and Weil, 1980:14) In addition, in designing model, one thing should be considered the student himself as a person who studies the lesson. It means that developing of a teaching design should be understood that how the students study the material easier than before (Sanjaya, 2008:67). The new Mingle model was discussed with the experts of teaching English through focus group discussion (FGD) at IAIN. Fourth step was implementing the new Mingle model. And the last was evaluation of model.

Observation was used to search and collect all information from the students and lecturers during teaching and learning English. Pre test and post test control group design was used as an experimental design (Creswell, 2009:313).

The subject of the research was the students who were taking English 2 at the second semester in 2012/2013 of academic year. There were 1493 students spread in five faculties at IAIN Imam Bonjol Padang taking English 2. Cluster random sampling technique was used to choose the sample of the research. There were 34 students of History major at $A d a b$ Faculty and 34 as class experiment and 34 students at counseling major at Tarbiyah an Teacher Training as class control. The experimental class was taught by using Mingle model and control class was taught by using conventional one.

The data of this research were students' achievement on all components of speaking skill. Observation was used to search and collect all information from the students and lecturers during teaching and learning English. Structure non participant was used to observe the students and lecturers activities in learning activities (Sugiyono, 2010:204). Questionnaire and interview were used to support the data collected.

The instruments of this research were questionnaire, check list and speaking test. Questionnaire was used to collect the information of English teaching process which had been conducted by the lecturers. Responsive test which proposed by Brown (2010:201) was used to test students speaking skill. Form of speaking test was in question and answers (Finocchayro, 1983: 72; Brown, 2010:201). The indicators were used to assess students' speaking skill were pronunciation, vocabulary, grammar, fluency and comprehension (Brown, 2010).

There were two types of data analysis, qualitative and quantitative. Qualitative analysis was used to describe the result of implementation Mingle model in teaching speaking skill. Quantitative analysis was used to describe the effect Mingle model in improving students speaking skill and analyze the gain score of experimental and control groups by using t-test. All the data were input into the computer, and then analyzed through the Statistical Package for Social Science (SPSS12.0). To be more specific, firstly, descriptive statistics such as frequencies means, and standard deviations were computed.

\section{RESEARCH FINDINGS}

The result showed that teaching process was insufficient to elaborate students' skill on speaking. Teaching process which was conducted by lecturers consisted four phases namely preparation, pre activity, main activity and post activity. However, those phases had not gained the aims of teaching speaking skill yet. The lecturers had prepared their lesson $77.20 \%$. Most of lecturers did not include speaking skill on their preparation for teaching. On 
their pre activity of teaching, $77.22 \%$ of lecturers did not do management of class such as seating arrangement. The lecturers just did main activity of teaching $61.02 \%$. It was included orientation of teaching, exploration of teaching, interpretation of teaching, and re-creation of teaching. Most lecturers focused their teaching on grammar and reading. They did not give opportunity maximally to individual of students. On post activity, the lecturers just did $70 \%$ of activity. Most of them did not evaluate the teaching process.

Developing Mingle model included standard competence, based competence, indicator of students' progress, and purposes of teaching, material of teaching at college level, Mingle model and evaluation. On Mingle model, there were pre, main, and post activities. Pre activity includes preparation. Main activities included orientation, exploration, interpretation, re-creation or confirmation, post activity included conclusion and reflection. The result of development of Mingle model included preparation; warming up; set the rule; act Mingle model; presentation; review and discussion.

In doing preparation, the lecturer did the following activities namely; the lecturer prepared the cards which had information in it or copy a few examples that the students wanted to learn and asked the students to sit at semi circle model. The activity on orientation was informing topic to the students. In this case, the lecturer informed the topic and explained the activities on Mingle model. On the Exploration activity included warming up, set the rule, and act Mingle. Warming up was the key of elaboration of Mingle model. The activities included the lecturer gave examples of expression which were used by the students, asked the students to follow the expression, asked the students speak to one another, and each of students got a change to speak. Set the rule was the following activity which conducted by the lecturer. This activity included informing the rules of Mingle includes way, time, and the way to win the game. Next was the lecturer shared the card to the students and divided the students into groups. Mingle activity included the lecturer shares the card to the students, set the time, asked the students to study the information firstly, asked the students to perform in group, asked the students to move around the class while completing the list of questions, monitored students' activities, and gave a change for each of students and groups to do mingle. The lecturers looked at the students' activities. In presentation, the lecturer gave a change to the winner to present it in front of the class. The lecturer asked the rest of students to pay more attention on pronunciation, grammar, fluency, vocabulary, and comprehension. After finishing the activities, the lecturer discussed with the students about the topic which had been studied. Next, the lecturer gave reinforcement of the topic and the students got the conclusion of the topic. The last activity of Mingle model assessed students' speaking ability. In this case, the way to assess students' speaking skill is role play. The students were given the card which had been written the instruction on it. The students did role playing in pairs or in groups based on instruction.

The implementation of Mingle model in speaking class gave significant effect toward students' skill on speaking at experimental class. It can be seen from the students' scores on the following tables below:

\section{Tabel 1}

\section{Data Description of Pre Test at Experimental and Control Class}

\begin{tabular}{l|l|l|l|l}
\hline \multirow{2}{*}{ Desc. } & \multicolumn{4}{|c}{ Pre-test and Post test } \\
\cline { 2 - 5 } & \multicolumn{2}{|l}{$\begin{array}{l}\text { Experimental Class } \\
\text { (SKI-A) }\end{array}$} & Control Class (MPI ) \\
\cline { 2 - 5 } & pre-test & $\begin{array}{l}\text { post- } \\
\text { test }\end{array}$ & $\begin{array}{l}\text { Pre } \\
\text { Test }\end{array}$ & Post test \\
\hline Resp & 34 & 34 & 34 & 34 \\
\hline Mean & 12.65 & 18.71 & 11.32 & 15.50 \\
\hline
\end{tabular}

Table 2

Data Description of Gain Score Both Experimental and Control Class

\begin{tabular}{l|c|c}
\hline Description & \multicolumn{2}{|c}{ Experimental and Control Classes } \\
\hline & Experimental Class & Control Class \\
\cline { 2 - 3 } & SKI-A & MPI \\
\hline Respondent & 34 & 32 \\
\hline Median & 5.50 & 3.00 \\
\hline Mean & 6.00 & 4.00 \\
\hline
\end{tabular}


Table 3

\section{Students' score on Speaking Skill before and after Giving Treatment}

\begin{tabular}{c|l|l|c|c|c|c}
\hline No & $\begin{array}{l}\text { Compo- } \\
\text { nent of } \\
\text { evaluation }\end{array}$ & Indicators & \multicolumn{2}{|l|}{$\begin{array}{l}\text { Before } \\
\text { treatment }\end{array}$} & \multicolumn{3}{|l}{$\begin{array}{l}\text { After } \\
\text { treatment }\end{array}$} \\
\hline 1 & $\begin{array}{l}\text { Teaching } \\
\text { speaking } \\
\text { skill } \\
\text { through }\end{array}$ & Fluency & 2.26 & $45.2 \%$ & 3.83 & $76.60 \%$ \\
\cline { 3 - 7 } Mingle & Vocabulary & 2.22 & $44.4 \%$ & 3.73 & $74.60 \%$ \\
\cline { 3 - 7 } & Grammar & 2.1 & $42.0 \%$ & 3.68 & $73.60 \%$ \\
\cline { 3 - 7 } & $\begin{array}{l}\text { Pronuncia- } \\
\text { tion }\end{array}$ & 2.20 & $44.0 \%$ & 3.51 & $70.20 \%$ \\
\cline { 3 - 7 } & $\begin{array}{l}\text { Comprehen- } \\
\text { sion }\end{array}$ & 2.14 & $42.8 \%$ & 3.69 & $73.90 \%$ \\
\cline { 3 - 7 } & $\begin{array}{l}\text { Mean of } \\
\text { score }\end{array}$ & 2.18 & $43.6 \%$ & 3.70 & $74.00 \%$ \\
\hline
\end{tabular}

The table above could be explained that the students' skill before giving the treatment was means score 2.18 or $43.6 \%$. After giving treatment with Mingle model, the students' achievement on speaking skill was 3.70 or $74 \%$. It meant that the students' skill on speaking got improvement. The result of treatment of Mingle model gave 30.4\% improvement toward students' skill on speaking. The following table was the hypothesis testing.

Table 4

Hypothesis Testing of Mingle Model

\begin{tabular}{|c|c|c|c|c|c|c|}
\hline \multirow[t]{2}{*}{ No } & \multirow{2}{*}{$\begin{array}{l}\text { Hypo- } \\
\text { thesis } \\
\text { (Ha } \\
\text { and } \\
\mathrm{H} 0 \text { ) }\end{array}$} & \multicolumn{2}{|c|}{$\begin{array}{l}\text { Gain Mean } \\
\text { score }\end{array}$} & \multirow{2}{*}{$\begin{array}{l}\text { t-test } \\
(\dot{\alpha}= \\
0,05)\end{array}$} & \multirow[t]{2}{*}{ Finding } & \multirow[t]{2}{*}{ Conclusion } \\
\hline & & $\begin{array}{l}\text { Experi } \\
\text { mental } \\
\text { Class }\end{array}$ & $\begin{array}{l}\text { Cont } \\
\text { rol } \\
\text { Clas } \\
\text { s }\end{array}$ & & & \\
\hline 1 & 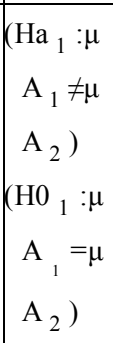 & 6.00 & 4.00 & $\begin{array}{l}\text { t- } \\
\text { count } \\
\text { ed=4. } \\
398 \\
\text { t-table= } \\
2,042 \\
\text { p- } \\
\text { value } \\
=0,00\end{array}$ & $\begin{array}{l}\mathrm{t}- \\
\text { counted } \\
>\mathrm{t} \text {-table } \\
\mathrm{p} \text {-value } \\
0,00 \\
<(\dot{\alpha}= \\
0,05) \\
\mathrm{Ha}{ }_{1} \text { acc } \\
\text { epted }\end{array}$ & $\begin{array}{l}\text { Model } \\
\text { Mingle was } \\
\text { more } \\
\text { effective at } \\
\text { class A1 than } \\
\text { class A2 }\end{array}$ \\
\hline
\end{tabular}

The table above showed that the first hypothesis was accepted $\left(\mathrm{Ha}_{1}: \mu \mathrm{A}_{1} \neq \mu \mathrm{A}_{2}\right)$. The mean gain score of students' achivement on speaking skill at experimental class at SKI major $(\bar{X}=6,00)$ and control class $(\bar{X}=4,00)$ was $\mathrm{t}_{\text {calculated }}=4,398$ and $p$-value in colom sig. (2-tailed) $=0,00$. The distribution score with the degree of freedom $\mathrm{t} d \mathrm{k}$ 33 and $(\dot{\alpha}=0,05)$ was gained that $\mathrm{t}_{t}$ 0.95(33) $=$
2,042 . It can be stated that $t_{\text {calculated }}(4,398)>\mathrm{t}$ table $(2,042)$ and $p$-value $(0,00)<\alpha=0,05)$. It could be concluded that there were significant differences between the students' speaking skill which was conducted by using Mingle model. Based the result of students' achievement by using Mingle model at experimental class, it was found that the recommended model of Mingle for teaching speaking skill at State Institute for Islamic Studies Imam Bonjol Padang. Mingle model can be seen as follows.

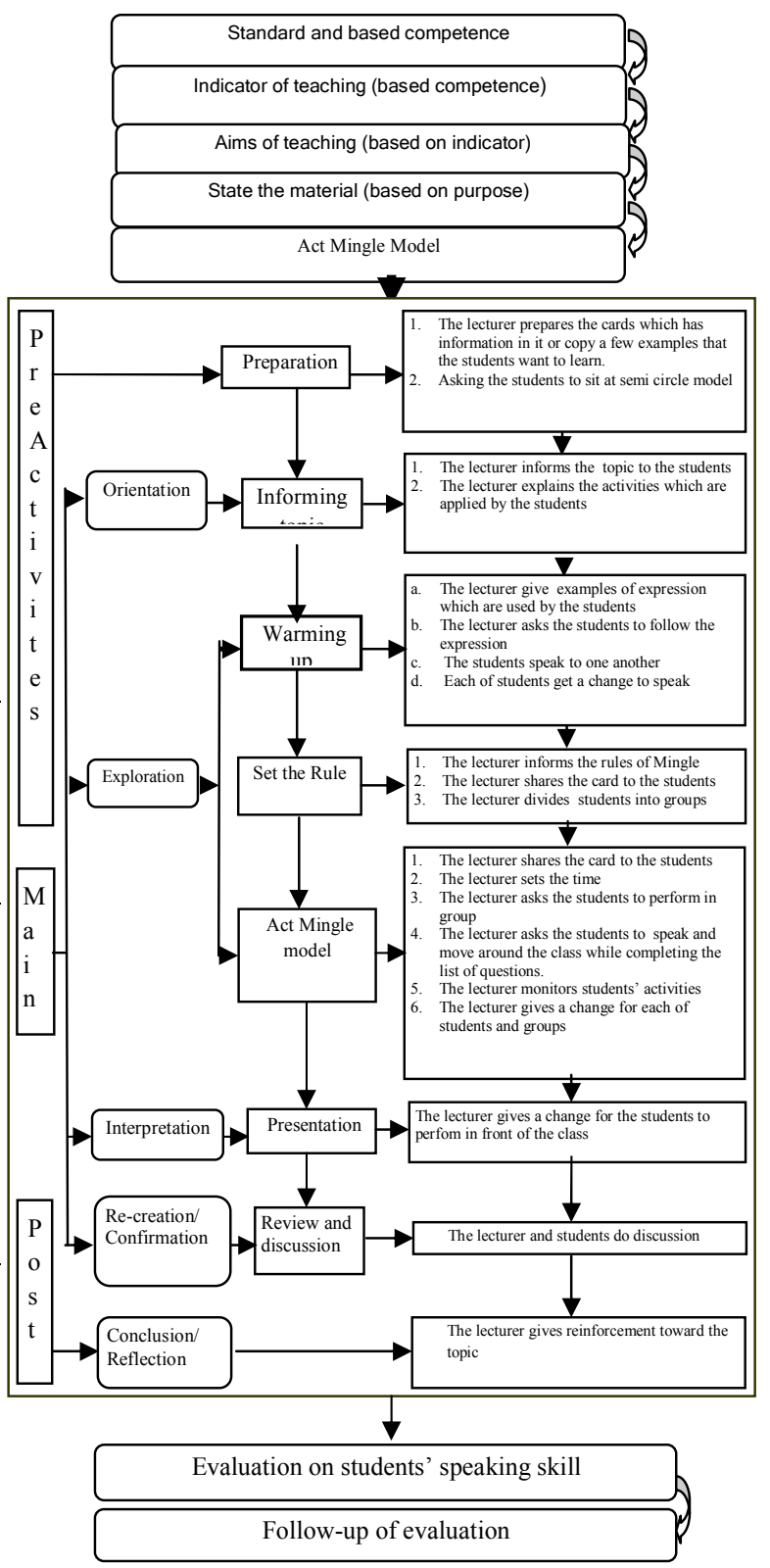

Figure 1. Mingle Model for Teaching Speaking Skill is Recommended 
The evaluation of implementing Mingle model was better to improve students' speaking skill. It could be seen on the following table.

Table 5

Evaluation on Teaching Process through Mingle Model

\begin{tabular}{l|l|l|c|c}
\hline No & Aspect & $\begin{array}{l}\text { Component of } \\
\text { Teaching } \\
\text { Process }\end{array}$ & Mean & $\begin{array}{l}\text { Precentage } \\
\mathbf{( \% )}\end{array}$ \\
\hline \multirow{2}{*}{$\begin{array}{l}\text { Teaching } \\
\text { Process }\end{array}$} & Preparation & 5.00 & 100.00 \\
\cline { 3 - 5 } & Pre-Activity & 4.80 & 96.00 \\
\cline { 3 - 5 } & Main Activity & 4.52 & 90.40 \\
\cline { 3 - 5 } & Evaluation & 4.77 & 95.40 \\
\hline
\end{tabular}

\section{DISCUSSION}

The result of the research of English teaching speaking process which had been conducting by the lecturers at State Institute for Islamic Studies Imam Bonjol Padang had not gained the purpose of teaching yet. Most of English lecturers did not encourage students' speaking individually. Most of the students were silent during teaching process. They tended to read rather than speak. The lecturers used to explain the material to the students. In addition, English lecturers tended to use traditional rows of seating. However, setting the seat in teaching process is conducted in order to make the students more active and more joy full (Harmer, 2001).

Furthermore, the relevant model to the students' need should be developed. Teaching through game is as one of model which can be used to encourage students' activity in learning at college level (Burns, 1997). Mingle is as a game that can be used to make the students more fun in learning.

Developing of Mingle model refers to Law of education which consists of standard competence, based competence, indicator of students' progress, and purposes of teaching, material of teaching at college level, Mingle model and evaluation which can be used as aguiding to teaching process (Joice, Weil \& Showers (1992:1).
Mingle model is included in three activities of teaching, namely pre, main, and post activities. Pre activity includes preparation. Main activities included orientation, exploration, interpretation, re-creation or confirmation, post activity included conclusion and reflection. Teaching process through Mingle model consists of five phases. Those are preparation, warming up, set the rule, act Mingle model, presentation, and discussion.

First, the lecturers should prepare the students to be ready to study. The students have to sit at semi circle model. The lecturers prepare the cards which have information in it or copy a few examples that the students want to learn. A variety of materials are appropriate to use in doing Mingle, including picture, texts. In order to help the students are able to speak English, the lecturers should give orientation. It includes informing topic and explaining the activities on Mingle model. After the students understand all information, the lecturers do exploration. There are three activities is included in exploring the students' skill on speaking, namely warming up, set the rule, and act Mingle. Mingle which proposed by Pollard did not have a warming activity. Giving warming up is the best way to open the teaching process (Gerand, 1982). It is better for the lecturer to lead the interaction first. The, invite the students to do that interaction to one another. In addition, Borzova (2008) added that in doing Mingle, it is suggested to give opportunity to do the interaction meaningfully. Next is the lecturer should state the rules to do mingle. This activity includes informing the rules of Mingle including way, time, and the way to win the game. In order to do the activity easily, it needs the clear rules which followed by the students. (Uberman, 1998).

Mingle activity includes sharing the card to the students, setting the time, asking the students to study the information firstly, asking the students to perform in group, asking the students to move around the class while completing the list of questions, monitoring students' activities, and giving a change for each of students and groups to mingle. The lecturers look at the students' activities. The 
students' activities are varied, including find out who, questionnaires, and surveys. These activities are also supported by Klippel (1984) and Seymour and Popova, (2003). They stated that find out who and surveys can be used to do mingle. Next activity of Mingle is presentation. The lecturer gives a change to the winner to present it in front of the class. The lecturer asks the rest of students to pay more attention on pronunciation, grammar, fluency, vocabulary, and comprehension. After finishing the activities, the lecturer discuss with the students about the topic which has been studied. Next, the lecturer gives reinforcement of the topic and the students get the conclusion of the topic. The last activity of Mingle model is doing assessment on students' speaking ability. Role play is an activity to evaluate students' speaking skill (Harmer, 2001; Brown, 2010).

Mingle model requires all students' involvement and they promote friendly competition; therefore, it is very important that students have a cooperative attitude. In addition, it is not only for more fun, but also more importantly, for the useful practice and review of language lessons, thus leading toward the goal of improving learners' communicative competence. So, it would be helpful if English lecturers adopt the model to gain the quality of learning process of English in speaking skill. Warm and friendly of lecturers are created if there is interaction between teachers and students (Prayitno, 2008).

Mingle model which has been shown above has advantages and effectiveness in learning speaking skill. First, Mingle brings in relaxation and fun for students. Second, Mingle model usually involves friendly competition and keeps learners interested. These activities create the motivation for learners of English to get involved and participate actively in the learning activities. Every student is involved to do interaction, including shy students. They are guided to start to speak. To reach understanding, they need to speak clearly and sometimes explain certain points or words as they adjust to a new partner. As a result, students feel both more relaxed and more involved. It can improve students' motivation, self-esteem fluency and active in interaction ( $\mathrm{Su}, 1995)$. Mingle can allow constant repetition of a particular question or collection of the opinions of many students. This gives students the opportunity to repeat the same utterance several times, which gradually raises confidence in their use of English Robertson and Acklam (2000). The students repeat for several times on the same expression. It causes the students are able to speak fluently (Harmer, 2001).

Therefore, Mingle promotes both accuracy and fluency, provided that they are properly organized into the lesson plan. Third, Mingle brings real world context into the classroom, and enhances students' use of English in a flexible, communicative way. Fourth, students' speaking skill can be better than before whether on their pronunciation, vocabulary, grammar, fluency, and comprehension. It can be seen on the students' score on speaking test. Students became more attentive and conscientious in class. They became more enthusiastic about practicing speaking.

The students get information through listening, looking at friends and reading as an input ability. They move and walk around and speak to one another. This activity will develop communicative competence. Communicative competence is the learners' ability to communicate effectively in a culturally significant setting (Hymes, 1972; Widdowson, 1978). Speaking to one another develops the learners' acquisition. The acquisition is the learners' mastery of the language. It produces the learner's fluency. The fluency is the learners' natural language without thinking of its structure and without translating the language into her/his native language. Finally, the comprehensible output is the learner's natural spoken performance which is understood by the listener.

In addition, using Mingle for teaching speaking skill can build a group. People are naturally cautious about sharing with each other the first time a group gets together, or when a group hasn't been together for a while, or when 
new members join the group. So, to get the most out of a group's time together, Mingle will jump start the sharing process by getting people talking to each other about things that matter. Second, it can increase trust. Mingle gives people permission to share at a deeper level than they usually do. Third, it meets others. Talking one on one with the other people in the room, especially the ones they don't know, or don't know well, helps people connect into the group at a personal level. Fourth, it encourages participation. By the time the group has finished both parts of the Mingle, asking the questions" and sharing the answers," everyone will have talked with most of the other people and probably have spoken in front of the whole group, so it's easier to do it again. Fifth, it is fun. The Mingle questions often provoke laughter and surprises. It provides a quick and easy way to learn something new about each other, and let others know a bit more about other people too. Sixth, it sets the tone. As facilitators, some of the most difficult moments are those first few when we can be faced with reluctance, hesitation, crossed arms and blank faces, or worse. The Mingle always shifts the atmosphere in the room to one of engagement, laughter and connection.

Harmer also stated that Mingle is one of collaborative activity which helps in developing communication skills and team building, help to break cultural barriers among students, lengthy icebreaker activities help in promoting a sense of trust and friendship between the students (2001). Pollard and Hess (1997:21) add that this excellent all the purpose communicative activity for big English classes. It is effective because it gets high level students' participation. It is also low inhibition level, encourage the students centered correction and free the teacher to observe the students' ability. It can be concluded that Mingle is as a joyful and communicative teaching.

\section{CONCLUSION AND RECOMMENDATION}

It is concluded that developing Mingle model has six procedures which can be applied in teaching speaking for the students. Those are preparation, warming up, set the rule, act mingle, presentation, and review and discussion. Mingle model is more effective to develop students' speaking skill at State Institute for Islamic Studies (IAIN) Imam Bonjol Padang. Mingle model gives learning opportunities individually to the students. Environment of learning through Mingle model gives a relaxed, pleasant learning atmosphere in the classrooms to the students. Warm and friendly of lecturers are created if there is interaction between teachers and students. By doing Mingle model, it allows the lecturer to create create numerous opportunities for students to try out varied activities for themselves, and by doing so they recycle, refine, and expand their personal experiences. The finding implies that the English lecturers have to use Mingle model to enhance the quality of teaching speaking skill on English subject especially at IAIN Imam Bonjol Padang, West Sumatera. It is suggested to English lecturers to use Mingle as an alternative model to improve students' speaking skill.

\section{REFERENCES}

Arrend, R.I. (1998). Learning to Teach. Singapore. Mc Graw-Hill book Company.

Brown, H. D \& Abeywickrama, P. (2010). Language Assesment: Principle and Classroom Practices. New York: Pearson Education Inc.

Brown, H. D. (1994). Teaching by Principles: Interactive Language Teaching Methodology. New York: Prentice Hall Regents.

Burns, A. \& Joyce, H. (1997). Focus on Speaking. Sydney: National Center for English Language Teaching and Research.

Castagnolo, C. (2009). Article Sources: http:/www//articlesbase.com.

Dick, W., \& Carey, L. (1996). The Systematic design of Instruction (4 th Ed). New York:Harper Collinc College Publisher. 
Eades, C. (2001). A Mingling of Minds: Collaboration and Modeling as Transformational Teaching Techniques. Focus on Basics: Connecting Research \& Practice, Volume 5, Issue B, October 2001.

Ersoz, A. (2000). Six Games for the EFL/ESL Classroom. The Internet TESL Journal, Vol VI, No 6 June.

Finnochiaro, M. \& Sako, S. (1983). Foreign Language Testing.USA: Regents Publishing Company, Inc.

Gerand, L. E. (1982). “ Using Warm-ups, Windups, and Fillers". Foreign Language Annals, 15 No 2, pp 95-99.

Harmer, J. (2001). The Practice of English Language Teaching. Pearson Education Ltd.

Harris, D. P. (1969) Testing English as Second Language. New Delhi: Tata McGraw-Hill Publishing Company Limited.

Huyen, N.T.T. \& Nga, K. T.T. (2003). Learning Vocabulary through Games. Asian EFL Journal, 5(4). Retrieved February 13, 2006, from http://www.asian-efljournal.com/dec 03 sub.Vn.php.

Hymes, D. (1972). On communicative competence. In J. B. Pride and J. Holmes (eds.): Sociolinguictics. Harmondsworth: Penguin.

Joyce, B., \& Weil, M. (1980). Model of Teaching. New Jersey: Prentice-Hall, Inc

Melor, S. (2003). First class mingle. Solution for English. Retrieved Agustus 2010. www. Onestopenglish.com.

Molenda, M. (2003). In Search of Elusive ADDIE Model. Indiana University.

Peraturan Pemerintah Nomor 37 Tahun 2009 tentang Standar Kualifikasi Dosen. Jakarta: Depdiknas.

Polard, L \& Hess, N. (1997). Zero Prep: Ready to go Activities for Teachers. Herforthshire. Prentice Hall.

Prayitno. (2008). Dasar Teori dan Praksis Pendidikan. Padang.UNP Press.
Silberman, M. (2008).Perencanaan dan Desain Sistem Pembelajaran. Jakarta: Kencana Prenada Media Group.

Silberman, M. (2009). Active Learning: 101 Strategies to Teach Any Subject.:Boston: Allyn and Bacon.

Su, K. L. (1995). Creative Games for the Language Class. Forum, Vol 33 No 1 January-March Page 35.

Uberman, A. (1998). The Use of Games for Vocabulary Presentation and Revision. Forum, 36(1), 20-27. Retrieved February 12, 2006,

Undang-Undang RI Nomor 14 Tahun 2005 Tentang Guru dan Dosen. Jakarta: Sinar Grafika.

Undang-Undang RI Nomor 20 Tahun 2003 Tentang Sistem Pendidikan Nasional. Jakarta: BP.Cipta Jaya

Widdowson, H.G.(1978). Teaching Language as Communication. Oxford: Oxford University Press.

Wright, A. (1993). Pictures for Language Learning. Cambridge: Cambridge University Press. 